\title{
Predictors of Performance of the ERP Adpopters in the Companies of LILAMA
}

\author{
Khanh Viet Tran ${ }^{1}$, Cuong Hung Pham ${ }^{2} \&$ Long Pham ${ }^{3}$ \\ ${ }^{1}$ LISEMCO. JSC, Vietnam \\ ${ }^{2}$ Foreign Trade University, Ho Chi Minh City Campus, Vietnam \\ ${ }^{3}$ National Economics University, Vietnam \\ Correspondence: Cuong Hung Pham, Foreign Trade University, Ho Chi Minh City Campus, \#15D5, Ward 25, Binh \\ Thanh District, Ho Chi Minh City, Vietnam.
}

Received: April 10, 2016

Accepted: May 4, 2016

Online Published: May 13, 2016

doi:10.5430/ijfr.v7n3p110

URL: http://dx.doi.org/10.5430/ijfr.v7n3p110

\begin{abstract}
This study is conducted in companies of Lilama. The results of this study are top management support refers to the executive sponsor (1) invest sufficient time, effort and resources to the project; (2) have a realistic understanding of the capabilities and limitation of the systems; (3) legitimize new goal and objective and ask questions before the project implemented ; (4) establish and approve new organizational structures, roles, policies and responsibilities; (5) monitor project process constantly; and (6) in times of conflict, managers should mediate between parties. The importance of the top management support is agreed by all researchers. The IT literature has clearly documented that for IT projects to succeed top management support is critical. It is said that top managers' understanding of the systems and IT is highly related to the quality of the top management support factors. The success of a project completely hinges on the strong, sustained commitment of top management. It is the first condition of any success ERP project. No support from the top managers, everything is hard to do.
\end{abstract}

Keywords: Enterprise Resources Planning (ERP), performamce, adpopters, LILAMA

\section{Introduction}

In a global business environment, firms are seeking to improve or maintain their competitiveness in the increasingly challenging global marketplace. Information systems are often used as tools to improve customer services; reduce cycle times, increase effectiveness, and decrease cost. Enterprise Resource Planning (ERP) systems have drawn interesting attention because they provide a variety of benefits to a business. ERP, which evolved from Manufacturing Requirements Planning (MRP), is an integrated information system that supports business processes and functions by managing the entire organization's resources efficiently and effectively. In other words, ERP involves the planning and managing of the organization's resources in the most efficient, productive, and profitable manner (Banker and Frolirk, 2003). It enables companies to integrate their business processes and all information relevant to their organization (Nah and Delgado, 2006). Kumar and Van Hillegersberg (2000) define it as configurable information systems packages that integrate information and business processes within and across functional boundaries within an organization. ERP is a comprehensive software solution that seeks to integrate the complete range of business from a single IT architecture (Al-Mashari et al., 2003). When companies have efficient business processes, they can be more competitive in the marketplace.

The benefits of ERP systems are linked to effectiveness and efficiency of business processes because firms can get more accurate and timely information (Trott and Hoecht, 2004). Through integrating business functions, firms can reduce data collection time and avoid data duplication. With timely information, ERP helps managers improve decision making speed and quality as well as facilities communication between users. Barriers between business functions and departments are lowered because an ERP system is a vehicle that integrates business processes across functional boundaries. Links with suppliers and customers can be significantly strengthened (Trott and Hoeacht, 2004). ERP systems improve coordination and facilitate cooperation with suppliers, and they improve responsiveness to market and customer requirements. ERP systems also allow firms to access electric commerce. Therefore, implementation and upgrades of ERP systems are identified as one of the top five IT priorities among global chief 
information officers (CIOs) (Beauty and Williams, 2006). A recent study by AMR Research indicates that the enterprise application market is expected to grow from \$28.8 billion in 2006 to $\$ 47.7$ billion by 2016 .

Many researchers have studied the reasons for ERP implementation (Finney and Corbett, 2007): Companies want to (1) integrate financial data; (2) standardize manufacturing process; (3) standardize human resource (HR) information; (4) have real-time information; (5) generate information for decision making; (6) reduce cost; (7) increase sales; (8) fulfill taxation requirements; and (9) respond to growing global competition. ERP systems can be comprehensive and useful in integrating many kinds of information processing abilities by placing data into a single database. Successful ERP implementation is quite beneficial to firms and provides them with competitive advantages (Teece et al., 1997). This explains why an ERP system is generally considered to be a vital element for enhanced business performance.

\section{Literature Review}

Enterprise Resource Planning (ERP) is a useful system to organize activities, decision, and information flows across many different functions and departments in a firm (Koh et al., 2008). ERP is the leading approach to integrate business management and information technology. Basoglu et al. (2007) defined ERP systems as integrate software solutions used to manage an organization's resources. According to Watson and Schneider (1998), ERP is an integrated, customized, packaged software-based system that handles the majority of an enterprise's system requirement in all functional areas, such as accounting, human resources, finance, sales, marketing, and manufacturing. ERP systems provide a seamless integration of all information flows in an organization to eliminate cross-functional coordination issues in the business process (Davenport, 1998). Through implementation of ERP system, firms can reduce the overall costs, make accurate data available in real time, and exchange information with customers and suppliers (Basoglu et al., 2007). Thus, a firm implementing an ERP system can have benefits such as fast and accurate information gathering, quick decision making, low inventory cost, improved interaction with customers, and improved product quality. Therefore, ERP can be defined as an integrated information system that supports the business processes and functions through managing the entire organization's resources efficiently and effectively.

Organizational performance measurement plays an important role in organizational growth. Through measuring performance, a firm can identify and track progress against organizational goals, seek opportunities for improvement, and compare performance against both internal and external standards. A firm can also formulate strategic activities through reviewing its performance. Academics and practitioners are interested in the relationship between information system investment and organizational performance (Ward and Zhou, 2006). Many researchers suggest that IT investment leads to improved firm performance including cost, quality, delivery, product variety, and timeto- market ( $\mathrm{Li}$ 2002). Most manufacturing firms place ERP implementation as a key technology priority in today's increasingly competitive and turbulent business environment. Keeping on top of the various activities and process involved in product production, sales, and distribution can be a tremendous challenge. Firms must design, built and deliver the highest quality products in the timeliest manner at the lowest costs to win and retain customers. With an ERP system, companies can leverage advanced features and functionality to improve all aspects of their operations from product development, sourcing and procurement, through manufacturing, quality testing, and to delivery. As a result, they can enhance efficiency and profitability by reducing cost, developing various products, introducing new products faster than competitors, delivering products on time, and improving quality.

Cost performance is referred to as the degree to which a firm can attract customers primarily at a low price (Krause et al., 2007). The most successful companies indentify needs and opportunities to substantially reduce costs in the supporting areas of their businesses. Reducing administrative costs, manual effort, and overhead can lead a firm to be more efficient, effective, responsive, and profitable. Through integrating business processes across departments onto a single enterprise- wide information system, ERP improves cross- functional coordination and increases efficiencies in doing business.

Product variety is referred to as the degree to which a firm introduces new goods and/ or services with additional features and improved performance with offering. Product variety aims to deliver variety levels that are compatible with market requirements and to improve the impact of product and part variety on the operations performances (Da Silveira, 1998). The literature on product variety has focused on its importance within competitive strategy (Uzemeri and Sanderson, 1995), its impact in operations performance (MacDuffie et al., 1996), and the use of flexibility for dealing with product and part variety in operations and strategy (Da Silveira, 1998). The importance of product variety has been increasing since 1990s (Uzemeri and Sanderson, 1995).

Delivery reliability is referred to as the degree to which a firm provides products or services according to the schedule promised at the time of sale. Shortages and quality problems in supplier parts are additional sources of product delay. Key benefits of an ERP system, such as enhanced control over component inventory, more precise 
demand planning, smooth production scheduling, and more effective coordination of distribution channels, enable firms to improve on- time delivery of products, a critical performance measure for today's manufacturers. Evidence shows that reliable suppliers can help buyers cut processing time, increase quality, and improve manufacturing competitiveness (Nahm et al., 2003).

Time- to- market is referred to as the degree to which a firm introduces new products faster than its competitors ( $\mathrm{Li}$, 2002). In turbulent rapid changing, and highly competitive markets, products have reduced life cycles. This means that there is a need for companies to reduce the time- to- market of new products that will simultaneously ensure their success in the market. Early products introduction improves profitability by extending a product's sales life and allowing development and manufacturing cost advantages. Researchers claim that earlier and faster product development leads to better performances (Griffin, 1997). The importance of time- to- market for new products as a factor of competitive advantage is well known. In fact, a considerable number of articles on this subject have been published in the last decade. Griffin (1997) used time- to- market as a dependent available and analyzed its relationship with the use of multifunctional teams, the use of formal processes of new product development, and the degree of product complexity and originality.

Quality is referred to as the degree to which a firm offers a product that creates a higher value for its customer (Mei, 2005). Firm that can respond faster to customer needs with quality products and innovative design, as well as excellent after- sales service, build customer loyalty, increase market share, and ultimately achieve increased profits (Mei, 2005). Garvin (1988) proposes eight dimensions of quality. These are performance, features, reliability, conformance, durability, serviceability, aesthetics, and perceived quality, which are comprehensive but difficult to establish to measure. ERP systems make it easier for businesses to check product defects and problems. ERP systems enable firms to identify exactly where the design or production process issue is occurring and to take the needed steps to make sure production of products of the supreme quality. This, in turn, will improve sales, customer satisfaction, and profits.

As specified in previous sections, this entire research framework is driven by constantly changing business environments, such as customer demand change, uncertain and rapid technological change. Thus, the real question is about how an ERP implementation can actually create higher value for customers. For this reason, the measure of the customer value" variable is included in this model. Customer value is referred to as the degree of benefits perceived by customers as a trade-off between what customers receive and what they sacrifice. Customer value is a source of competitive advantage for business firms. Tu (1999) defined it as the extent to which customers perceive a firm's products as having higher value, as well as their degree of satisfaction with these products. However, the customer' perceived value can easily be confused with customer satisfaction (Sweeney and Soutar, 2001). While perceived value occurs at various stages of the purchasing process, customer satisfaction and referral are more related to postpurchase and post- use evaluation (Sweeney and Soutar, 2001). Customer value comes from meeting the current needs of customers more efficiently, from identifying the customer needs proactively, and from meeting new customer needs or new needs of existing customers (Chand et al., 2005). Customer value is also related to improve customer service and more accurate customer invoices. To faster customer service a firm can also connect new systems to the ERP system (e.g. a system optimizing distribution routes). An ERP system enables faster response to customers. For example, a firm reported improvement in the customer response for orders with a fulfillment period of less than one week. The new ERP system helped to meet these delivery terms. It also enabled faster and more accurate customer reports regarding project stages, the tasks of project members, and time spent on performing respective tasks.

Value for money is referred to as the degree to which a customer perceives value because a firm has lowered a product's price (Joo, 2007). It is the value that customers perceive the price of a product purchased is lower than average market price. Value for money is related to what a customer sacrifices in order to buy a product (Petrick, 2002). Some customers may know the exact price of the product they purchased, but others may only evaluate the price based on their past purchases. Customers feel that they purchased products with high value and quality. This may be perceived due to cost reductions or a lower price. ERP system enable firms to facilitate quicker data/ information flow between departments and offices and helps employees to work faster, save valuable time, and reduce operational costs. As a result, customers can perceive cost saving in their purchases.

Convenience is referred to as the degree to which a customer perceived value because the firm has provided convenient information and service (Joo, 2007). Customers experience convenience due to timely and update information. Valid delivery promises and fulfilling customer orders on time through using an ERP system improves customer service. An ERP system enables a firm to develop customer order quotations faster and even more accurately, improve job estimating, and shorten delivery lead times. As a result, customers can perceive convenience in their purchases. Convenience along with timely response is included in non- monetary costs. 
Timely response is referred to as the degree to which a customer perceives time saving because a firm quickly acts upon customer needs (Joo, 2007). Through the experience of quick services, such as order fulfillment and delivery, customers can perceive time saving. ERP systems enable the organizations to response to any challenges in real time, so that a firm is able to respond in a timely fashion to any customer demands. ERP systems also allow for timely and accurate responses to customer problems and priorities.

The critical success factors in the left side of the model are identified from literature. We searched and listed the factors mentioned in prior studies. The descriptive language differs slightly by different scholars. We traced the content of each factor and categorized them by the real meaning. After comparison and combination, seven factors were identified. They are: (1) top management support (TMS), (2) training and education (TE), (3) project management (PM), (4) departmental communications (DC), (5) cultural adaptability (CA), (6) software competence and IT skills (CITS), and (7) hardware and equipment (HE). With the identified CSFs, the research model is specified.

\section{ERP Critical Success Factors}

1. Top management support (TMS)

2. ERP Training and Education (TE)

3. ERP Project Management (PM)

4. Department Communications (DC)

5. Cultural Adaptability (CA)

6. Software Competence and IT skills (CITS)

7. Hardware and Equipment (HE)

Figure 1. Research model

H1: There are positive relationships between "ERP dimensions" and "market and profitability"

$\mathrm{H} 2$ : There are positive relationships between "ERP dimensions" and "customer satisfaction"

H3: There are positive relationships between "ERP dimensions" and "order time"

H4: There are positive relationships between "ERP dimensions" and "employee satisfaction"

H5: There are positive relationships between "ERP dimensions" and "process efficiency"

H6: There are positive relationships between "ERP dimensions" and "process effectiveness"

\section{Research Method}

This study adopted a deductive approach and best fits in the positivism and objectivism positions, while explaining the epistemological and ontological considerations. Thus, quantitative methodology was selected for this research project. The self-completion questionnaire survey method was used to collect the data. This data collection method was selected in view of constraints like cost, time, and the nature of the study. The perception based data about the implementation of ERP was collected from the managers of companies of Lilama. The self-completion questionnaire was prepared. A pilot testing of the questionnaire was conducted. Individuals from various backgrounds (academics, ERP experts and company managers) participated in the design and pilot testing of the questionnaire. A total of 135 questionnaires were sent to one hundred companies which were members of Lilama. Different statistical tools and techniques like descriptive statistics, correlations, multiple regression were used to analyze the data. The selection of any statistical tool and technique for specific research questions was based on the nature of the variables in each research question. The data was analyzed by using SPSS 22, one of the most widely used analytical software tools in social and management sciences. 


\section{Research Results}

Table 1 shows the reliability of the construct - top management support. As shown, the Cronbach alpha for the construct is 0.975 that is very high (greater than 0.7 ) and the Cronbach alpha if item deleted for all the items of top management support is less than or equal 0.975 . In a word, we can conclude that the construct top management support has a very high reliability.

Table 1. Item-Total Statistics for top management support

\begin{tabular}{ccccc}
\hline & $\begin{array}{c}\text { Scale Mean if Item } \\
\text { Deleted }\end{array}$ & $\begin{array}{c}\text { Scale Variance if } \\
\text { Item Deleted }\end{array}$ & $\begin{array}{c}\text { Corrected Item-Total } \\
\text { Correlation }\end{array}$ & $\begin{array}{c}\text { Cronbach's Alpha if Item } \\
\text { Deleted }\end{array}$ \\
\hline ERP11 & 32.4444 & 46.532 & .919 & .971 \\
ERP12 & 32.5852 & 46.946 & .947 & .969 \\
ERP13 & 32.5704 & 47.098 & .932 & .970 \\
ERP14 & 32.6519 & 47.273 & .933 & .970 \\
ERP15 & 32.6000 & 49.212 & .902 & .972 \\
ERP16 & 32.6519 & 49.378 & .876 & .974 \\
ERP17 & 32.8074 & 50.709 & .864 & .975 \\
\hline
\end{tabular}

Table 1 shows the reliability of the construct - training and education. As shown, the Cronbach alpha for the construct is 0.903 that is very high (greater than 0.7 ) and the Cronbach alpha if item deleted for all the items of training and education is less than or equal 0.975. In a word, we can conclude that the construct training and education has a very high reliability.

Table 2. Item-Total Statistics for training and education

\begin{tabular}{ccccc}
\hline & $\begin{array}{c}\text { Scale Mean if Item } \\
\text { Deleted }\end{array}$ & $\begin{array}{c}\text { Scale Variance if } \\
\text { Item Deleted }\end{array}$ & $\begin{array}{c}\text { Corrected Item-Total } \\
\text { Correlation }\end{array}$ & $\begin{array}{c}\text { Cronbach's Alpha if Item } \\
\text { Deleted }\end{array}$ \\
\hline ERP21 & 20.2222 & 15.816 & .711 & .894 \\
ERP22 & 20.6593 & 15.435 & .714 & .895 \\
ERP23 & 20.1704 & 16.366 & .793 & .876 \\
ERP24 & 20.3556 & 15.738 & .843 & .865 \\
ERP25 & 20.1333 & 16.863 & .763 & .883 \\
\hline
\end{tabular}

Table 2 shows the reliability of the construct - project managemet. As shown, the Cronbach alpha for the construct is 0.929 that is very high (greater than 0.7) and the Cronbach alpha if item deleted for all the items of project management is less than or equal 0.929 . In a word, we can conclude that the construct project management has a very high reliability.

Table 3. Item-Total Statistics for project management

\begin{tabular}{ccccc}
\hline & $\begin{array}{c}\text { Scale Mean if Item } \\
\text { Deleted }\end{array}$ & $\begin{array}{c}\text { Scale Variance if } \\
\text { Item Deleted }\end{array}$ & $\begin{array}{c}\text { Corrected Item-Total } \\
\text { Correlation }\end{array}$ & $\begin{array}{c}\text { Cronbach's Alpha if Item } \\
\text { Deleted }\end{array}$ \\
\hline ERP31 & 27.5111 & 22.610 & .763 & .919 \\
ERP32 & 27.6741 & 21.997 & .815 & .912 \\
ERP33 & 27.6000 & 22.212 & .827 & .911 \\
ERP34 & 27.6593 & 23.301 & .730 & .923 \\
ERP35 & 27.5333 & 23.131 & .804 & .914 \\
ERP36 & 27.6148 & 22.746 & .818 & .912 \\
\hline
\end{tabular}

Table 3 shows the reliability of the construct - departmental communication. As shown, the Cronbach alpha for the construct is 0.965 that is very high (greater than 0.7) and the Cronbach alpha if item deleted for all the items of departmental communication is less than or equal 0.965 . In a word, we can conclude that the construct departmental communication has a very high reliability. 
Table 4. Item-Total Statistics for departmental communication

\begin{tabular}{ccccc}
\hline & $\begin{array}{c}\text { Scale Mean if Item } \\
\text { Deleted }\end{array}$ & $\begin{array}{c}\text { Scale Variance if } \\
\text { Item Deleted }\end{array}$ & $\begin{array}{c}\text { Corrected Item-Total } \\
\text { Correlation }\end{array}$ & $\begin{array}{c}\text { Cronbach's Alpha if Item } \\
\text { Deleted }\end{array}$ \\
\hline ERP41 & 31.0074 & 46.455 & .849 & .962 \\
ERP42 & 31.0148 & 46.418 & .854 & .961 \\
ERP43 & 30.7481 & 45.130 & .902 & .958 \\
ERP44 & 30.7185 & 45.577 & .905 & .958 \\
ERP45 & 30.7333 & 46.167 & .909 & .957 \\
ERP46 & 30.7704 & 47.074 & .917 & .957 \\
ERP47 & 30.4741 & 48.624 & .803 & .965 \\
\hline
\end{tabular}

Table 4 shows the reliability of the construct - cultural adaptability. As shown, the Cronbach alpha for the construct is 0.955 that is very high (greater than 0.7 ) and the Cronbach alpha if item deleted for all the items of cultural adaptability is less than or equal 0.955 . In a word, we can conclude that the construct cultural adaptability has a very high reliability.

Table 5. Item-Total Statistics for cultural adaptability

\begin{tabular}{ccccc}
\hline & $\begin{array}{c}\text { Scale Mean if Item } \\
\text { Deleted }\end{array}$ & $\begin{array}{c}\text { Scale Variance if } \\
\text { Item Deleted }\end{array}$ & $\begin{array}{c}\text { Corrected Item-Total } \\
\text { Correlation }\end{array}$ & $\begin{array}{c}\text { Cronbach's Alpha if Item } \\
\text { Deleted }\end{array}$ \\
\hline ERP51 & 23.5630 & 12.158 & .885 & .942 \\
ERP52 & 23.5037 & 12.312 & .871 & .945 \\
ERP53 & 23.3778 & 12.282 & .926 & .936 \\
ERP54 & 23.6741 & 12.624 & .862 & .946 \\
ERP55 & 23.7778 & 12.682 & .828 & .952 \\
\hline
\end{tabular}

Table 5 shows the reliability of the construct - software competence and IT skills. As shown, the Cronbach alpha for the construct is 0.912 that is very high (greater than 0.7) and the Cronbach alpha if item deleted for all the items of software competence and IT skills is less than or equal 0.912. In a word, we can conclude that the construct software competence and IT skills has a very high reliability.

Table 6. Item-Total Statistics for software competence and IT skills

\begin{tabular}{ccccc}
\hline & $\begin{array}{c}\text { Scale Mean if Item } \\
\text { Deleted }\end{array}$ & $\begin{array}{c}\text { Scale Variance if } \\
\text { Item Deleted }\end{array}$ & $\begin{array}{c}\text { Corrected Item-Total } \\
\text { Correlation }\end{array}$ & $\begin{array}{c}\text { Cronbach's Alpha if Item } \\
\text { Deleted }\end{array}$ \\
\hline ERP61 & 16.7185 & 9.457 & .811 & .883 \\
ERP62 & 16.7407 & 10.238 & .795 & .889 \\
ERP63 & 16.8593 & 9.331 & .806 & .885 \\
ERP64 & 16.6148 & 10.149 & .799 & .888 \\
\hline
\end{tabular}

Table 6 shows the reliability of the construct - hardware and equipment. As shown, the Cronbach alpha for the construct is 0.89 that is very high (greater than 0.7 ) and the Cronbach alpha if item deleted for all the items of hardware and equipment is less than or equal 0.89. In a word, we can conclude that the construct hardware and equipment has a very high reliability.

Table 7. Item-Total Statistics for hardware and equipment

\begin{tabular}{ccccc}
\hline & $\begin{array}{c}\text { Scale Mean if Item } \\
\text { Deleted }\end{array}$ & $\begin{array}{c}\text { Scale Variance if } \\
\text { Item Deleted }\end{array}$ & $\begin{array}{c}\text { Corrected Item-Total } \\
\text { Correlation }\end{array}$ & $\begin{array}{c}\text { Cronbach's Alpha if Item } \\
\text { Deleted }\end{array}$ \\
\hline ERP71 & 24.5481 & 6.608 & .692 & .876 \\
ERP72 & 24.7333 & 6.764 & .663 & .882 \\
ERP73 & 24.6000 & 6.749 & .795 & .853 \\
ERP74 & 24.5778 & 6.679 & .774 & .856 \\
ERP75 & 24.5926 & 6.781 & .750 & .862 \\
\hline
\end{tabular}


A phase of data reduction through factor analysis was necessary before the examination of the relationship between ERP success factors and organizational performance. Factor loadings of the data set of 39 items developed based on the seven dimensions of ERP was analyzed by principal component analysis and Varimax rotation. As a result, seven factors were extracted. As mentioned, in order to provide empirical evidence supporting the appropriateness of the data for unidimensionably, the Kaiser-Mayer-Olkin (KMO) measure of sampling adequacy was used. As a guideline, $\mathrm{KMO}$ values in the $.50 \mathrm{~s}$ or above were relevant, and below $.50 \mathrm{~s}$ were unacceptable (Hair et al., 1998).

Table 8. Rotated Component Matrix for ERP items

\begin{tabular}{|c|c|c|c|c|c|c|}
\hline & \multicolumn{6}{|c|}{ Component } \\
\hline & 1 & 2 & 3 & 4 & 5 & 6 \\
\hline ERP11 & & .806 & & & & \\
\hline ERP12 & & .858 & & & & \\
\hline ERP13 & & .852 & & & & \\
\hline ERP14 & & .834 & & & & \\
\hline ERP15 & & .809 & & & & \\
\hline ERP16 & & .814 & & & & \\
\hline ERP17 & & .839 & & & & \\
\hline ERP21 & & & & & .681 & \\
\hline ERP22 & & & & & .771 & \\
\hline ERP23 & & & & & .731 & \\
\hline ERP24 & & & & & .860 & \\
\hline ERP25 & & & & & .816 & \\
\hline ERP31 & & & & . 640 & & \\
\hline ERP32 & & & & .697 & & \\
\hline ERP33 & & & & .751 & & \\
\hline ERP34 & & & & .778 & & \\
\hline ERP35 & & & & .763 & & \\
\hline ERP36 & & & & .766 & & \\
\hline ERP41 & .799 & & & & & \\
\hline ERP42 & .794 & & & & & \\
\hline ERP43 & .885 & & & & & \\
\hline ERP44 & .877 & & & & & \\
\hline ERP45 & .876 & & & & & \\
\hline ERP46 & .878 & & & & & \\
\hline ERP47 & .719 & & & & & \\
\hline ERP51 & & & .859 & & & \\
\hline ERP52 & & & .830 & & & \\
\hline ERP53 & & & .883 & & & \\
\hline ERP54 & & & .798 & & & \\
\hline ERP55 & & & .784 & & & \\
\hline ERP61 & .534 & & & & & \\
\hline ERP62 & .508 & & & & & \\
\hline ERP63 & .656 & & & & & \\
\hline ERP64 & .622 & & & & & \\
\hline ERP71 & & & & & & .649 \\
\hline ERP72 & & & & & & .612 \\
\hline ERP73 & & & & & & .793 \\
\hline ERP74 & & & & & & .858 \\
\hline ERP75 & & & & & & .842 \\
\hline
\end{tabular}

\section{Results from Regression Models}

Before building multiple regression models, the study provides the correlation matrices among the seven criteria of ERP, and between organizational performance and ERP. The bivariate correlation of the seven independent variables 
is shown in the following table. All the correlations between the seven independent variables and the six dependent variables are displayed. Examination of the correlation matrix indicates that all the seven criteria of ERP are closely correlated with the six factors of organizational performance.

It is proposed that there was a correlation between the seven criteria of ERP and the organizational performance. If true, each of the measures of the organizational performance should be correlated to the seven criteria of ERP. The six measures of the organizational performance are each used as dependent variables in the regression model and the seven criteria of ERP are used as the independent variables. In addition, it is hypothesized that:

H1: There are positive relationships between "ERP dimensions" and "market and profitability"

$\mathrm{H} 2$ : There are positive relationships between "ERP dimensions" and "customer satisfaction"

H3: There are positive relationships between "ERP dimensions" and "order time"

H4: There are positive relationships between "ERP dimensions" and "employee satisfaction"

H5: There are positive relationships between "ERP dimensions" and "process efficiency"

H6: There are positive relationships between "ERP dimensions" and "process effectiveness"

The six models (ERP-P1; ERP-OP2; ERP-P3; ERP-P4; ERP-P5; ERP-P6) are statistically significant at less than 1 percent, and the regression coefficients (beta coefficient) of the significant factors are provided. Since six measures of the organizational performance are found to have significant correlation with the criteria of ERP, the propositions are supported.

In model ERP-P1 with 'market and profitability' as the dependent variable, ERP3 is significant at $\mathrm{p}<.05$; ERP7 is significant at $\mathrm{p}<.01$. These items have regression correlations with market and profitability. This partially supported Hypothesis 1. This implies that the improvement in ERP3 and ERP7 will result in better market and profitability of the organizations. The largest impact on market and profitability is ERP7 (beta coefficient $=.275$ ). In model ERP-P2 with 'customer satisfaction' as the dependent variable, ERP3 is significant at $\mathrm{p}<.05$; ERP7 is significant at $\mathrm{p}<.01$. These items have regression correlations with customer satisfaction. This partially supported Hypothesis 2. Hence, effective ERP3 and ERP7 will result in increased customer satisfaction. ERP7 made the highest influence on customer satisfaction (beta coefficient $=.303$ ), ERP3 (.293). In model ERP-P3 with 'order time' as the dependent variable, 2 items ERP3 and ERP7 are statistically significant at $p<.05$ and .01 , respectively. Hypothesis 3 is partially supported. When the activities of ERP3 and ERP7 are emphasized, order time will be improved. ERP7 has beta coefficient of .320 and .244 for ERP3. In model ERP-P4 with 'employee satisfaction' as the dependent variable, one factor is statistically significant at $\mathrm{p}<.1$, namely, ERP7. Hypothesis 4 is partially supported. When the activities of ERP7 are emphasized, employee satisfaction increases. ERP7 has beta coefficient of .189. In model ERP-P5 with 'process efficiency' as the dependent variable, one factor is statistically significant at $\mathrm{p}<.1$, namely, ERP7. Hypothesis 5 is partially supported. When the activities of ERP7 are emphasized, process efficiency increases. ERP7 has beta coefficient of .194. In model ERP-P6 with 'process effectiveness' as the dependent variable, 2 items are statistically significant at $p<.1$ and .01 , namely, ERP1 and ERP7. Hypothesis 6 is partially supported. When the activities of ERP1 and ERP7 are emphasized, process effectiveness increases. ERP1 and ERP7 have beta coefficient of .201 and .298 respectively

Table 9. Correlation matrix of ERP dimensions

\begin{tabular}{|c|c|c|c|c|c|c|c|}
\hline & ERP1 & ERP2 & ERP3 & ERP4 & ERP5 & ERP6 & ERP7 \\
\hline ERP1 & 1.00000 & & & & & & \\
\hline ERP2 & $.563 * *$ & 1.00000 & & & & & \\
\hline ERP3 & $.489 * *$ & $.478 * *$ & 1.00000 & & & & \\
\hline ERP4 & $.542 * *$ & $.451 * *$ & $.561 * *$ & 1.00000 & & & \\
\hline ERP5 & $.481 * *$ & $.314 * *$ & $.571 * *$ & $.316^{* *}$ & 1.00000 & & \\
\hline ERP6 & $.611 * *$ & $.501 * *$ & $.595 * *$ & $.710 * *$ & $.530 * *$ & 1.00000 & \\
\hline ERP7 & $.450 * *$ & $.368 * *$ & $.471 * *$ & $.357 * *$ & $.540 * *$ & $.589 * *$ & 1.00000 \\
\hline
\end{tabular}

**: Pearson Correlation is significant at the .01 level (2-tailed) 
Table 10. Correlation matrix of ERP dimensions

\begin{tabular}{lccccccc}
\hline & ERP1 & ERP2 & ERP3 & ERP4 & ERP5 & ERP6 & ERP7 \\
\hline ERP1 & 1.00000 & & & & & & \\
ERP2 & $.563^{* *}$ & 1.00000 & & & & & \\
ERP3 & $.489^{* *}$ & $.478^{* *}$ & 1.00000 & & & & \\
ERP4 & $.542^{* *}$ & $.451^{* *}$ & $.561^{* *}$ & 1.00000 & & & \\
ERP5 & $.481^{* *}$ & $.314^{* *}$ & $.571^{* *}$ & $.316^{* *}$ & 1.00000 & & \\
ERP6 & $.611^{* *}$ & $.501^{* *}$ & $.595^{* *}$ & $.710^{* *}$ & $.530^{* *}$ & 1.00000 & \\
ERP7 & $.450^{* *}$ & $.368^{* *}$ & $.471^{* *}$ & $.357^{* *}$ & $.540^{* *}$ & $.589^{* *}$ & 1.00000 \\
\hline
\end{tabular}

**: Pearson Correlation is significant at the .01 level (2-tailed)

Table 11. Correlation matrix of ERP and performance

\begin{tabular}{ccccccc}
\hline & P1 & P2 & P3 & P4 & P5 & P6 \\
\hline ERP1 & $.248^{* *}$ & $.201^{* *}$ & .232 & $.246^{* *}$ & $.237^{* *}$ & $.271^{* *}$ \\
ERP2 & $.205^{* *}$ & $.218^{* *}$ & .151 & $.169^{* *}$ & $.129^{* *}$ & $.182^{* *}$ \\
ERP3 & $.353^{* *}$ & $.351^{* *}$ & .336 & $.199^{* *}$ & $.234^{* *}$ & $.231^{* *}$ \\
ERP4 & $.136^{* *}$ & $.131^{* *}$ & $.199^{* *}$ & $.181^{* *}$ & $.146^{* *}$ & $.202^{* *}$ \\
ERP5 & $.331^{* *}$ & $.291^{* *}$ & $.287^{* *}$ & $.271^{* *}$ & $.282^{* *}$ & $.202^{* *}$ \\
ERP6 & $.156^{* *}$ & $.129^{* *}$ & .156 & $.157^{* *}$ & $.183^{* *}$ & $.126^{* *}$ \\
ERP7 & $.347^{* *}$ & $.339^{* *}$ & .347 & $.262^{* *}$ & $.283^{* *}$ & $.294^{* *}$ \\
\hline
\end{tabular}

**: Pearson Correlation is significant at the .01 level (2-tailed)

Table 12. Multiple regression of ERP on performance

\begin{tabular}{|c|c|c|c|c|c|c|c|c|c|c|}
\hline \multirow{3}{*}{ ERP } & \multicolumn{10}{|c|}{ Performance } \\
\hline & \multicolumn{2}{|c|}{$\mathrm{P} 1$} & \multicolumn{2}{|c|}{$\mathrm{P} 2$} & \multicolumn{2}{|c|}{ P3 } & \multicolumn{2}{|c|}{ P4 } & \multicolumn{2}{|c|}{ P5 } \\
\hline & Beta & $p$-value & Beta & p-value & Beta & p-value & Beta & $p$-value & Beta & $p$-value \\
\hline ERP1 & .102 & .361 & .030 & .790 & .097 & .392 & .128 & .280 & .133 & .264 \\
\hline ERP2 & .034 & .734 & .084 & .405 & -.051 & .616 & .029 & .785 & -.047 & .658 \\
\hline ERP3 & .268 & .020 & .293 & .011 & .244 & .035 & -.013 & .913 & .081 & .502 \\
\hline ERP4 & -.003 & .979 & .025 & .839 & .149 & .224 & .155 & .228 & .031 & .807 \\
\hline ERP5 & .138 & .206 & .099 & .363 & .091 & .408 & .189 & .103 & .144 & .214 \\
\hline ERP6 & -.316 & .025 & -.354 & .012 & -.365 & .010 & -.249 & .093 & -.136 & .359 \\
\hline ERP7 & .275 & .009 & .303 & .004 & .320 & .003 & .189 & .090 & .194 & .082 \\
\hline $\begin{array}{c}\text { Multiple } \\
\text { R }\end{array}$ & \multicolumn{2}{|c|}{.468} & \multicolumn{2}{|c|}{.465} & \multicolumn{2}{|c|}{.454} & \multicolumn{2}{|c|}{.351} & \multicolumn{2}{|c|}{.346} \\
\hline $\mathrm{R}$ square & \multicolumn{2}{|c|}{.219} & \multicolumn{2}{|c|}{.216} & \multicolumn{2}{|c|}{.206} & \multicolumn{2}{|c|}{.123} & \multicolumn{2}{|c|}{.120} \\
\hline F ratio & \multicolumn{2}{|c|}{5.078} & \multicolumn{2}{|c|}{5.007} & \multicolumn{2}{|c|}{4.716} & \multicolumn{2}{|c|}{2.552} & \multicolumn{2}{|c|}{2.465} \\
\hline $\begin{array}{l}\text { p-value } \\
\text { of F ratio }\end{array}$ & \multicolumn{2}{|c|}{.000} & \multicolumn{2}{|c|}{.000} & \multicolumn{2}{|c|}{.000} & \multicolumn{2}{|c|}{.017} & \multicolumn{2}{|c|}{.021} \\
\hline
\end{tabular}


For ERP-P6 (process effectiveness), beta values are $\mathbf{0 . 2 0 1} ; 0.013 ; 0.086 ; 0.199 ; 0.035 ;-0.391 ;$ and 0.298, respectively and $\mathrm{p}$-values are $\mathbf{0 . 0 8 4} ; 0.904 ; 0.463 ; 0.114 ; 0.755 ; 0.008 ; \mathbf{0 . 0 0 7}$, respectively. Multiple $\mathrm{R}=0.403 ; \mathrm{R}$ square $=0.163 ; \mathrm{F}$ ratio $=3.521, \mathrm{p}$-value $=\mathbf{0 . 0 0 2}$

\section{Conclusion}

Concerning performance improvement of Lilama's companies, a conceptual framework was developed in this study. This framework was used not only to evaluate the practices of ERP, but also to examine the relationship between ERP practices and organizational performance. The sample of the study includes companies of Lilama. The total sample size was 135, in which 90 from companies (66.67\% of the total sample) already had ERP implementation and 45 from companies (33.33\% of the total sample) did not have. A set of seven dimensions of ERP was considered from various academic and practitioner perspectives. They included top management support, training and education, project management, departmental communication, cultural adaptability, software competence and IT skills, and hardware and equipment. The measures of ERP were empirically tested to be reliable and valid.

This study evaluated the impact of ERP dimensions on performance by testing six hypotheses:

H1: There are positive relationships between "ERP dimensions" and "market and profitability"

$\mathrm{H} 2$ : There are positive relationships between "ERP dimensions" and "customer satisfaction"

H3: There are positive relationships between "ERP dimensions" and "order time"

H4: There are positive relationships between "ERP dimensions" and "employee satisfaction"

H5: There are positive relationships between "ERP dimensions" and "process efficiency"

H6: There are positive relationships between "ERP dimensions" and "process effectiveness"

Through the multiple regression analysis, the six hypotheses were partially statistically significant. This implies that ERP implementation is really a good way to improve organizational performance.

\section{References}

Akkermans, H., \& Helden, van K. (2002). Vicious and virtuous cycles in ERP implementation: a case study of interrelations between critical success factors. European Journal of Information Systems, 11, 35-46

Aladwani, A. M. (2001). Change management strategies for successful ERP implementation. Business Process management Journal, 6(3), 266-275.

Chen, I. J. (2001). Planning for ERP systems: analysis and future trend. Business Process Management Journal, 7(5), 374-386.

Clemmons, S., \& Simon, S. J. (2001). Control and coordination in global ERP configuration. Business Process Management Journal, 7(3), 205-215.

Clouther, S. (2002). ERP market to rebound. Transportation and Distribution, 42(2), 18.

Evans, R. (1994). The human side of business process re-engineering. Management Development Review, 7(6), 10-12.

Gulla, J. A., \& Brasethvik, T. (2000). On the challenges of the business modelling in large-scale reengineering projects. Nowergian University of Science and Technology.

Hawa, M., Ortiz, A., Lario, F., Ros, L. (2002). Improving the role played by humans in the development of enterprise engineering integration projects through training based on multimedia, International journal of Computer Integrated Manufacturing, 15(4), 335-344.

Holland, Light, \& Gibson. (1999). A critical success factors model for enterprise resource planning implementation. Proceedings of the $7^{\text {th }}$ European Conference on Information Systems. Copenhagen Business School, Copenhagen, pp. 273-287.

Hong, K-K., \& Kim, Y-G. (2002). The critical success factors for ERP implementation: an organizational fit perspective. Information and Management, 40, 25-40.

Kumar, V., Maheshwari, B., \& Kumar, U. (2003). An investigation of critical management issues in ERP implementation: empirical evidence from Canadian organizations. Technovation, 23(10), 793-807.

Marjanovic, O. (2000). Supporting the "soft" side of business process reengineering. Business Process Management Journal, 6(1), 43 . 
Markus, M. L., \& Tanis, C. (1999). The Enterprise System Experience - From Adaption to Success. Claremont Graduate University, California.

Markus, M. L., Axline, S., Petrie, D., \& Tanis, C. (2000). Learning from the adapters' experiences with ERP: problems encountered and success achieved. Journal of Information Technology, 15, 145-265.

May, D., \& Kettelhut, M. C. (1996). Managing human issues in reengineering projects: a case review of implementation issues. Journal of Systems management, 47(1), 5-11.

Mital, A. (1997). What role for humans in computer integrated manufacturing? International Journal of Computer Integrated Manufacturing, 10(1-4), 190-198.

O’Leary, D.E. (2000). Enterprise recourse planning systems: systems, life cycle, electronic commerce and risk. Cambridge University Press.

Olson, D. L. (2004). Managerial Issues of Enterprise Resource PlanningSystems. McGraw- Hill/Irwin.

Parr, A., \& Shanks, G. (2000). A model of ERP project implementation. Journal of Information Technology, 15, 289-303.

Poston, R., \& Grabski, S. (2001). Financial impacts on enterprise resource planning implementations. International Journal of Accounting Information Systems, 2, 271-294.

Ross, J. W. (1999). Surprising facts about implementing ERP. IT Pro, July/August.

Skok, W., \& Legge, M. (2002). Evaluating enterprise resource planning systems using an interpretive approach. Knowledge and Process Management, 9(2), 72-82.

Somers, T. M., \& Nelson, K. G. (2001). The impact of critical success factor across the stages of enterprise resource planning implementation. Proceedings of the $34^{\text {th }}$ Hawaii International Conference on Systems Sciences, January 3-6, Mauni, Hawaii.

Somers, T. M., \& Nelson, K. G. (2004). A taxonomy of players and activities across the ERP project life cycle. Information and Management, 41, 257-278.

Stewart, G., Milford, M., Jewels, T., Hunter, T., \& Hunter, B. (2000). Organizational readiness for ERP implementation. Information Systems Management Research Centre, Queensland University of Technology. Americas Conference in Information Systems (AMCIS).

Sumner, M. (2000). Risk factors in enterprise wide/ ERP projects. Journal of Information Technology, 15, 317-327.

Sutciffe, N. (1999). Leadership behavior and business process reengineering (BPR) outcomes: an empirical analysis of 30 BPR project. Information and Management, 36(5), 273-286.

Umble, E. J., Haft, R. R, \& Umble, M. M. (2003). Esterprise resource planning: implementation procedures and critical success factors. European Journal of Operational Research, 146(2), 241-257.

Wateridge, J. (1997). Training for IS/IT project managers: a way forward. International Journal of Project Management, 15(5), 283-288.

Welti, N. (1999). Successful SAP R/3 implementation: Practical management of ERP projects. Pearson Education Limited.

Willcocks, L.P., \& Sykes, R. (2000). The role of the CIO and IT function in ERP: asleep or at a wheel. Communications of the ACM, 43(4), 22-28.

Zucchi, F., \& Edwards, J. S. (1999). Human resource management aspects of business process reengineering: a survey. Business Process Management Journal, 4(4), 325. 